\title{
A COMMUNITY OF SECRETS: STIGMATIZATION OF FORMER HANSEN'S DISEASE PATIENTS AND THEIR GENERATIONS IN KAMPUNG SINAR BARU, SARAWAK, MALAYSIA
}

\author{
Parveen Kaur \\ Universiti Malaysia Sarawak, Malaysia \\ sspkaur@unimas.my \\ Atiqah Abd-Rahim \\ Universiti Malaysia Sarawak, Malaysia \\ 16020186@siswa.unimas.my \\ (Corresponding author) \\ Anis Jahoring \\ Universiti Malaysia Sarawak, Malaysia \\ anisjahoring7@gmail.com \\ Joanna Edut \\ Universiti Malaysia Sarawak, Malaysia \\ joannaedut94@gmail.com \\ Arif Jawaid \\ Linton University College \\ arifjawaid@ktgeducation.edu.my
}

*Corresponding author sspkaur@unimas.my 


\title{
A COMMUNITY OF SECRETS: STIGMATIZATION OF FORMER HANSEN'S DISEASE PATIENTS AND THEIR GENERATIONS IN KAMPUNG SINAR BARU, SARAWAK, MALAYSIA
}

\begin{abstract}
In the early $19^{\text {th }}$ century in Sarawak, Hansen's disease or leprosy became a reportable disease where the unfortunate victims were forcibly segregated to a leprosarium, leaving behind family, relatives and future. The image of claw hands or toes and rot noses were associated with the unclean and the sinful. This chronic transmissible affliction made a great panic to the state government to ostracize sufferers in an isolated settlement back in the 1920s. Fortunately, the infection can be cured but negative attitudes towards the former leprosy patients persist until now. This paper is based on ethnographic work that explores the stigma experienced and challenges faced by former leprosy patients and their generation. The research findings are based on three months of fieldwork with seven former sufferers and three children of former sufferers who live in Kampung Sinar Baru, Kota Padawan, Sarawak, a resettlement village for the former leprosy patients. The findings reveal their dreadful past experiences on compulsory segregation in Rajah Charles Brooke Memorial Hospital (RCBMH) where they were forced to be separated from family and hometown which still haunt them till today. In addition, former patients suffer mental health consequences and humiliation from the effects of treatment and also from visible deformities. Nevertheless, they believe that the stigmatization is less severe now than in the past and empathy from society makes them become more independent.
\end{abstract}

Keywords: stigma, Hansen's disease, affliction, Sarawak, ethnography 